Available online on 15.03.2020 at http://jddtonline.info
Open Access to Pharmaceutical and Medical Research
unrestricted non-commercial use, provided the original work is properly cited

Open@ Access

Research Article

\title{
Efficacy of Aqueous Crude Fruit Extract of Desert Date (Balanites aegyptiaca) in Anaesthetization of African Catfish (Clarias gariepinus) Fingerlings
}

\author{
*Audu Idi Wakawa and Abubakar Chiroma \\ Department of Biology, Umar Suleiman College of Education, Gashua, Yobe State, Nigeria
}

\begin{abstract}
Chemicals have been used to anaesthetize fish but due to their hazardous effects on the environment, fish and humans environmentally friendly plant anaesthetics are being sought. Fruit of Desert date (Balanites aegyptiaca) is nontoxic to humans but has been reported to have anaesthetic potentials on fish. This study investigates anaesthetic effect of aqueous crude fruit extract of B. aegyptiaca on African catfish (Clarias gariepinus) fingerlings. Phytochemical and proximate compositions of the fruit were screened. Exactly 120 C. gariepinus fingerlings (mean weight $32.13 \pm 2.43 \mathrm{~g}$ and mean total length $23.88 \pm 2.11 \mathrm{~cm}$ ) were used for the experiment. A total of 10 fingerlings were exposed to each of $2.00,2.50$, $3.00,3.50$ and $4.00 \mathrm{~g} / \mathrm{L}$ concentrations of aqueous crude fruit extract of B. aegyptiaca and a control in 6 plastic tanks (45x28x25cm) filled with $10 \mathrm{~L}$ of tap water. Setup was arranged in randomized block design and replicated. Temperature, dissolved oxygen, $\mathrm{pH}$, free carbon dioxide and total alkalinity were monitored. Results revealed long mean induction (25.05 $\pm 3.35 \mathrm{~min})$ and recovery $(108.35 \pm 2.45 \mathrm{~min})$ times with resultant mortalities $(40 \%)$ of $C$. gariepinus fingerlings. significant correlation $(\mathrm{P}<0.01)$ exists between concentration of the fruit extract and induction time as well as between fruit extract concentrations and survival of fingerlings. Aqueous crude fruit extract of $B$. aegyptiaca is, therefore, not effective for anaesthetization of $C$.gariepinus fingerlings hence should be avoided.
\end{abstract}

Keywords: Anaesthetic, Balanites aegyptiaca, Clarias gariepinus

Article Info: Received 07 Jan 2020; Review Completed 11 Feb 2020; $\quad$ Accepted 19 Feb 2020; Available online 15 March 2020

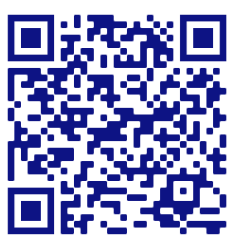

Cite this article as:

Wakawa AI, Chiroma A, Efficacy of Aqueous Crude Fruit Extract of Desert Date (Balanites aegyptiaca) in Anaesthetization of African Catfish (Clarias gariepinus) Fingerlings, Journal of Drug Delivery and Therapeutics. 2020; 10(2):45-52 http://dx.doi.org/10.22270/jddt.v10i2.3859

Audu Idi Wakawa, Department of Biology, Umar Suleiman College of Education, Gashua, Yobe State, Nigeria

\section{INTRODUCTION}

Aquaculture manipulations and transportation cause stress in fish which result into suppression of immunity, physical injury, or even death (Neiffer \& Stamper, 2009) ${ }^{1}$. The stress caused by aquaculture practices could be avoided through anaesthesia. According to Javahery \& Moradlu (2012)2, anaesthesia is a biological state with complete loss of sensation or loss of voluntary neuromotor control caused by chemical or non chemical means. Anaesthetics are therefore used to immobilize fish for easy handling during aquaculture practices such as harvesting or capturing, sorting, tagging, sampling, artificial reproduction procedures and surgery (Matin, Hossain \& Hashim, 20003; Javahery, Nechoubin \& Moradlu, 20124).

Stuart $(1985)^{5}$ reported that the widely used chemical anaesthetics for fish anaesthesia have gradually changed so much so that many of the first generation anaesthetics are now out of use due to health hazards, lack of adequate efficacy and adverse physiological effects on fish
(Ramanayaka \& Atapattu, 2006) 6. In aquaculture chemical anaesthetics are gradually replaced with organic ones such Tricane Methanesulphate (MS-222), benzocaine, etomidate, metomidate, 2-phenoxyethanol, quinaldine, quinaldine sulphate, ketamine, and eugenol (Hajek, Kłyszejko, Dziaman, $2006^{7}$ and Neiffer \& Stamper, 2009)1. Out of these anaesthetics only MS-222 has been permitted for use in food fish anaesthesia mainly due to environmental and health risks (Marking \& Mayer, 19858; Ramanayaka \& Atapattu, $2006^{6}$ ) hence the search for environmentally friendly plant anaesthetics (Marking \& Mayer, 1985; Kamble, Saini, \& Ojha, 20149') becomes necessary. This study therefore seeks to find out the efficacy of aqueous fruit extract of Balanites aegyptiaca in anaesthetization of Clarias gariepinus fingerlings.

\section{The Experimental Plant (B. aegyptiaca)}

Balanites aegyptiaca commonly called Desert date, Soapberry tree, Egyptian balsam or thorn tree (Chothani \& Vaghasiya, 2011) 10 is a member of the family 
Zygophyllaceae. In northern Nigeria it is commonly referred to as 'Aduwa' by the Hausa tribe while the Fulani tribe calls it 'Tanni' (Onyema, Chinedu \& Ahmad, 2017) 11. It is called 'mchunju' by Swahilis, 'Hingot' by Indians and 'Heglig' by Arabs while Amharics in Ethiopia call it 'Bedena' (Tesfaye, 2015) ${ }^{12}$. It is a deep-rooted, evergreen or semi-deciduous, multi-branched, spiny tree which grows up to $12 \mathrm{~m}$ in height. The fruit of $B$. aegyptiaca is an ellipsoid drupe, about 2.5$4.0 \mathrm{~cm}$ long and $1.2 .0 \mathrm{~cm}$ in diameter (Tesfaye, 2015) 12 . The ripe fruit is brown or pale brown to yellow and resembles a small date. In humans the edible bitter-sweet pulp is used as food or confectionary, and laxative as well as for the treatment of constipation (Nkunya, Weenen, \& Bray, 1990) ${ }^{13}$.

\section{Phytochemical Constituents of B. aegyptiaca and other Plants}

Salihu, Nwozo \& Oloyede (2013) ${ }^{14}$ screened the fruit mesocarp of B. aegyptiaca collected from Ilorin, Kwara State, Nigeria and reported presence of alkanoids, saponin, steroid, flavonoids, and cardiac glycosides. Absalom, Nwadiaro \& Wophill (2013) ${ }^{15}$ also worked on the fruit mesocarp collected from Jos, Nigeria and reported presence of alkaloids, tannins, saponins, anthraquinones, steroids, flavonoids and cardiac glycosides as active ingredients. Similarly, Vijay, Nivedita, \& Bellundagi (2013) ${ }^{16}$ collected $B$. aegyptiaca fruit from Rajasthan Jaipur, India and reported the presence of alkanoids, flavonoids, glycosides, saponins, and terpenoids. In their phytochemical screening, Kumar, Sangeetha, Suchitra, Ravishinkar, \& Yashovarma (2016) ${ }^{17}$ also reported the presence of amino acids, carbohydrates, steroids, saponins coumarins and triterpenoids while alkanoids, tannins, flavonoids and phenols were absent in the fruit of B. aegyptiaca from Udupi, India.

\section{Proximate Composition of $B$. aegyptiaca and other Plants}

Proximate composition of plant parts have been documented by many authors. Umar, Abubakar, Alhassan, Yahaya, Hassan, \& Sani (2014) ${ }^{18}$ reported analyzed the flower of $B$. aegyptiaca and reported $10.8 \%$ crude protein, $43.3 \%$ moisture and $4.50 \%$ crude lipid. Ekpete, Edori \& Fubara $\left(2013^{19}\right)$ reported $1.28 \%$ crude protein, $0.53 \%$ crude lipid, $80.53 \%$ moisture content and $0.21 \%$ crude fibre for fruit of Psidium guajava while Marcel \& Bievenu (2012) 20 reported 24.18 and $25.37 \%$ crude protein for Hippocratea myriantha and Urera Trinervis leaves respectively. Percentage crude protein of Brassica oleracea reported by Emebu \& Anyika $(2011)^{21}$, was $11.67 \%$ while moisture content and crude fibre were 81.38 and $3.00 \%$ respectively. Raimi, Oyekanmi \& Farombi (2014)22 reported $21.16 \%$ crude protein for Manihot esculentus and $18.80 \%$ for Ceiba pentandra leaves while moisture content were $4.85 \%$ for Manihot esculentus and $5.30 \%$ for Ceiba pentandra leaves. Marcel \& Bievenu $(2012)^{20}$ earlier reported $24.18 \%$ crude protein for Urera trinervis leaf. Achi, Onyeabo, Ekelem-Egedigwe, \& Onyeanula (2017) ${ }^{23}$ proximately analyzed leaves of Ficus capensis and reported $104 \%$ moisture, $6.65 \%$ ash, $6.31 \%$ crude protein and 73.77 carbohydrate.

\section{The Experimental Fish (C. gariepinus)}

The African catfish (C. gariepinus) is a large, eel-like fish, usually of dark gray or black coloration on the back, fading to a white belly. C. gariepinus has an average adult length of $1-1.5 \mathrm{~m}$. African catfish can weigh up to $60 \mathrm{~kg}$ (Froese, Rainer \& Pauly, Daniel, 2014) 24 These fish have slender bodies, flat bony heads and broad, terminal mouths with four pairs of barbels. They also have large accessory breathing organs composed of modified gill arches (Froese, et al., 2014) 24.
Though C. gariepinus is hardy and tolerates poor water quality conditions, it is susceptible to stress during transportation and aquaculture practices such as sorting, tagging, artificial reproduction procedures, sampling and harvesting (Javahery et al., 2012) ${ }^{4}$. C. gariepinus is found throughout Africa and the Middle East, and live in freshwater lakes, rivers, and swamps, as well as humanmade habitats, such as oxidation ponds or even urban sewage systems (Clay, 1989) ${ }^{25}$.

\section{MATERIALS AND METHODS}

\section{Place of Collection of Balanites aegyptiaca Fruits}

The fruits of the experimental plant (Balanites aegyptiaca) were collected from Gashua, Bade Local Government Area of Yobe State; North-eastern Nigeria. The State borders the Nigerian states of Bauchi, Borno, Gombe, and Jigawa. It also borders Diffa and Zinder Regions of the Republic of Niger to the North. The climatic conditions of the state are hot and dry for most of the year, except in the southern part of the state which has a milder climate due to its location in the dry Savannah belt (Hamidu, 2010) ${ }^{26}$.

Bade Local Government Area, one of the seventeen local government areas of Yobe State, has its Headquarters at Gashua. It is located in the north-western part of the state at $12^{\circ} 52^{\prime \prime} 5^{\circ} \mathrm{N} 11^{\circ} 2^{\prime \prime} 47^{\circ} \mathrm{E}$. It is bordered in the North by Karasuwa Local Government area, in the south by Jakusko Local Government area, in the east by Bursari Local Government area and in the west by Jigawa state, Nigeria (Hamidu, 2010) 26.

\section{Obtaining Fruits of B. aegyptiaca and C. gariepinus Fingerlings}

. The fruit of the plant was collected in Gashua, Bade local Government area of Yobe state. A quantity of $1 \mathrm{~kg}$ of ripe fruits was collected from five (5) B. aegyptiaca plants located $3 \mathrm{~km}$ north of Gashua town. The fruits were collected by deliberately striking the branches of the plant with a long stick and the dropped ripe fruits were handpicked.

A quantity of 120 freshly caught $C$. gariepinus fingerlings was obtained from artisanal fishermen along River Yobe and transported in two oxygenated cellophane bags (60 fingerlings per bag) to Biology laboratory of Umar Suleiman College of Education, Gashua for acclimation.

\section{Preparation of Fruit of B. aegyptiaca}

The obtained fruits of the experimental plant were washed with clean water several times to remove soil, dust or dirt. A quantity of $1 \mathrm{~kg}$ of the fruit was shade dried to prevent the loss of active components. The dried samples were pulverized with pestle and mortar and sieved with $0.5 \mathrm{~mm}$ sieve into fine powder and stored in an airtight plastic container.

\section{Acclimation of $C$. gariepinus Fingerlings}

The experimental fish (C. gariepinus Fingerlings) were acclimated at Biology Laboratory of Umar Suleiman College of Education, Gashua, Yobe State, Nigeria in six 20L capacity round plastic tanks (20 fingerlings per tank) for 14 days. Fingerlings were fed to satiation with commercial feed (Vital $\left.{ }^{\circledR}\right)$ twice daily. Water was changed every other day while uneaten feed and faecal matter were siphoned out daily. Fish were starved 24 hours prior to the experiment.

\section{Phytochemical Screening of Pulverized Crude Fruit of $B$. aegyptiaca}

Standard phytochemical test was carried out on the pulverized crude fruit using methods of Trease \& Evans 
(1984) 27 and Soforowa (1982) 28 to determine the presence of Alkaloids, flavonins, saponins, tannins, cardiac glycosides, and terpens \& steroids. Others are balsams, phenols, and resins.

\section{Determination of Proximate Composition of Pulverized Crude Fruit of B. aegyptiaca}

The proximate composition of the pulverized crude fruit of B. aegyptiaca was determined using the standard methods of Association of Official Analytical Chemist (AOAC) (2003) 29. The following parameters were examined: moisture content, crude protein, crude fat, and fibre as well as ash contents.

Preparation of Definitive Sedative Concentrations of Pulverized Crude Fruit of B. aegyptiaca

Prior to the administration of the crude fruit extract to the experimental fish, preliminary experimental trials (Audu, Omirinde, Gosomji \& Wazhi, 2017) ${ }^{30}$ were carried out to determine suitable concentrations for the experiment. Subsequent to series of experimental trials 5 concentrations $(2.00,2.50,3.00,3.50$ and $4.00 \mathrm{~g} / \mathrm{L})$ of crude fruit extract of $B$. aegyptiaca were determined as definitive sedative concentrations.

\section{Experimental Design}

The experiment consists of 12 rectangular plastic tanks $(45 \times 28 \times 25 \mathrm{~cm})$ and 120 O. niloticus fingerlings (mean weight $32.13 \pm 2.43 \mathrm{~g}$ and mean total length $23.88 \pm 2.11 \mathrm{~cm}$ ) arranged in randomized block design (Rezende, Pascoal, Vianna \& Lanna, 2017) ${ }^{31}$. Each of the six (6) tanks were filled with $10 \mathrm{~L}$ of tap water, with 5 of the filled tanks inoculated with graded levels of aqueous crude fruit extract of $B$. aegyptiaca and ten (10) 0 . niloticus fingerlings were introduced and labeled A1, B1, C1, D1 and E1 while the sixth tank (F1) that was not inoculated with the test material served as the control. Setup was replicated in Tanks A2, B2, C2, D2, E2 and F2.

\section{Procedure for Anaesthesia of $C$. gariepinus fingerlings}

Anaesthetic stages were determined as suggested by Summerfelt \& Smith (1990) ${ }^{32}$ and Javahery \& Moraldu $(2012)^{2}$. The fingerlings were simultaneously exposed to the concentrations of the plant material and observed for behavioural changes. Behavioural responses of exposed fingerlings were compared with those in the control tanks. The behavioural changes at each stage were noted and any fingerling that attained state of anaesthesia (Total loss of reflex) in any tank was removed and placed in a corresponding recovery tank containing untainted water. The times of removal and recovery of each fish were noted.

Exposure of $C$. gariepinus fingerlings to Treatment Concentrations

To each of the concentrations of the fruit extract, $10 \mathrm{C}$. gariepinus fingerlings were exposed by immersion method (Neifer \& Stamper, 2009) 25 in tanks A1, B1, C1 D1 and E1. The remaining batch of 10 fingerlings was exposed to the control tank (F1). The setup was replicated in tanks A2, B2, C2, D2, and E2. Tank F2 served as the replicate control.

\section{Monitoring of Water Quality Parameters}

The standard methods of American Public Health Association (APHA) (1985) ${ }^{33}$ was used to monitor water quality parameters such as temperature, dissolved oxygen (DO), free carbon dioxide $\left(\mathrm{CO}_{2}\right)$, total alkalinity (TA), and hydrogen ion concentration $(\mathrm{pH})$ of the experimental tanks.

\section{Data Analyses}

SPSS statistical package (version 20) was used to analyze the data. Analysis of Variance (ANOVA) was used to determine the difference in treatment means while separation of treatment means was by Tukey's multiple comparisons test. Pearson's correlation coefficient was used to determine relationship between treatment concentrations and time of anaesthesia.

\section{RESULTS}

\section{Phytochemical Screening of Crude Fruit of B. aegyptiaca}

The results of the screened crude fruit of B. aegyptiaca using water solvent are presented in Table 1 . Screening of the crude fruit extract using different tests confirmed the presence of alkanoids, flavonoids, tannins, saponins and terpenoids. Others are balsam, carbohydrates, phenols and resins. Cardiac glycosides were not confirmed in the crude fruit of B. aegyptiaca.

Table 1: Phytochemical Screening of Crude Fruit of B. aegyptiaca using Water as Solvent

\begin{tabular}{|l|l|l|l|}
\hline PHYTOCHEMICAL & FRUIT & COLOUR & TEST \\
\hline Alkanoids & + & Orange & Dragendoff's \\
\hline Flavonoids & + & Cream light yellow & Lead acetate \\
\hline Tannins & + & Deep blue & Ferric chloride \\
\hline Saponins & ++ & Honeycomb froth & Foam test \\
\hline Terpens \& Steroids & + & Reddish brown ring & Burchard's \\
\hline Cardiac glycosides & - & - & Salkowki's \\
\hline Balsam & + & Dark green & General test \\
\hline Carbohydrates & + & Blue-black & Benedict's \\
\hline Phenols & + & Deep bluish green & - \\
\hline Resins & + & Violet & - \\
\hline
\end{tabular}




\section{Proximate Analyses of Crude Fruit of B. aegyptiaca}

Proximate analyses of Fruit of B, aegyptiaca revealed 16.40\% crude protein, $11.60 \%$ crude fibre, and $10.90 \%$ crude lipid. Moisture content was $3.56 \%$ and Nitrogen free extract (NFE) constitutes $50.03 \%$ of the total nutrients (Table 2).

Table 2: Proximate Composition of Crude Fruit of B. aegyptiaca obtained from Gashua, Yobe State, Nigeria

\begin{tabular}{|l|l|}
\hline PARAMETER & $\begin{array}{l}\text { PERCENTAGE } \\
\text { COMPOSITION (\%) }\end{array}$ \\
\hline Crude protein & 16.40 \\
\hline Crude fibre & 11.60 \\
\hline Crude lipid & 10.90 \\
\hline Ash content & 8.00 \\
\hline Moisture content & 3.56 \\
\hline Nitrogen Free Extract (NFE) & 49.54 \\
\hline
\end{tabular}

\section{Water Quality Analyses of Crude Fruit of B. aegyptiaca}

Water quality parameters of experimental tanks during anaesthesia of $C$. gariepinus fingerlings with concentrations of aqueous crude fruit extract of B. aegyptiaca are presented in Table 3. Mean DO decreased with increase in fruit extract concentration. Control recorded mean DO of $5.55 \pm 0.20 \mathrm{mg} / \mathrm{L}$ but declined to $2.05 \pm 0.65 \mathrm{mg} / \mathrm{L}$ in the lowest concentration $(2.00 \mathrm{~g} / \mathrm{L})$ of the extract. The mean DO concentration steadily decreased from $1.50 \pm 0.50 \mathrm{mg} / \mathrm{L}$ in treatment concentration $2.50 \mathrm{~g} / \mathrm{L}$ to $0.8 \pm 0.30 \mathrm{mg} / \mathrm{L}$ in $4.00 \mathrm{~g} / \mathrm{L}$. Free $\mathrm{CO}_{2}$, however, increased with increase in concentration of the plant extract. Lowest free $\mathrm{CO}_{2}(2.60 \pm 0.10 \mathrm{mg} / \mathrm{L})$ was recorded in fruit extract concentration $2.00 \mathrm{~g} / \mathrm{L}$ while the highest value $(16.15 \pm 0.25 \mathrm{mg} / \mathrm{L})$ was recorded in the highest concentration $(4.00 \mathrm{~g} / \mathrm{L})$ of the fruit extract. TA also increased with increase in plant extract concentration. Lowest TA $(33.50 \pm 3.50 \mathrm{mg} / \mathrm{L})$ was noted in the control followed by the least extract concentration $(2.00 \mathrm{~g} / \mathrm{L})$ which recorded $73.00 \pm 9.00 \mathrm{mg} / \mathrm{L}$. TA steadily increased to its peak $(150.00 \pm 15.00 \mathrm{mg} / \mathrm{L})$ in the highest extract concentration $(4.00 \mathrm{~g} / \mathrm{L})$. There are no significant variations $(\mathrm{P}>0.05)$ in $\mathrm{pH}$ and temperature of treatment tanks compared with the control. There is, however, significant correlation $(\mathrm{P}<0.01)$ between fruit extract concentrations and $\mathrm{DO}$, free $\mathrm{CO}_{2}$ and TA concentrations. Increase in fruit extract concentration decreases DO while increase in the extract concentration increases free $\mathrm{CO}_{2}$ and TA concentrations.

Table 3: Mean Water Quality Parameters of Experimental Tanks during Anaesthesia of C. gariepinus Fingerlings with Concentrations of Aqueous Crude Fruit Extract of B. aegyptiaca

\begin{tabular}{|l|l|l|l|l|l|l|}
\hline \multirow{2}{*}{ Parameter } & \multicolumn{5}{|c|}{ Concentrations (g/L) } \\
\cline { 2 - 7 } & 0.00 & 2.00 & 2.50 & 3.00 & 3.50 & 4.00 \\
\hline DO (mg/L) & $5.55 \pm 0.20$ & $2.05 \pm 0.65^{*}$ & $1.50 \pm 0.50^{*}$ & $1.10 \pm 0.40^{*}$ & $1.05 \pm 0.45^{*}$ & $0.80 \pm 0.30^{*}$ \\
\hline Temperature ( $\left.{ }^{\circ} \mathrm{C}\right)$ & $29.00 \pm 1.00$ & $29.00 \pm 1.00$ & $29.00 \pm 1.00$ & $30.00 \pm 2.00$ & $30.00 \pm 2.00$ & $30.00 \pm 2.00$ \\
\hline $\mathrm{pH}$ & $7.40 \pm 0.20$ & $7.15 \pm 0.15$ & $6.85 \pm 0.05$ & $6.70 \pm 0.20$ & $6.60 \pm 0.20$ & $6.50 \pm 0.10$ \\
\hline Free $\mathrm{CO}_{2}(\mathrm{mg} / \mathrm{L})$ & $2.60 \pm 0.10^{*}$ & $13.1 \pm 0.10^{*}$ & $13.15 \pm 1.45^{*}$ & $15.00 \pm 3.00^{*}$ & $15.45 \pm 1.75^{*}$ & $16.15 \pm 0.25^{*}$ \\
\hline TA $(\mathrm{mg} / \mathrm{L})$ & $33.50 \pm 3.50$ & $73.00 \pm 9.00$ & $91.50 \pm 2.50^{*}$ & $93.00 \pm 3.00^{*}$ & $115.50 \pm 2.50^{*}$ & $150.00 \pm 15.00^{*}$ \\
\hline
\end{tabular}

Values with Asterisks $\left({ }^{*}\right)$ in the same row are significantly different compared with the control

\section{Anaesthetic Effect of Crude Fruit Extract of B. aegyptiaca on C. gariepinus fingerlings}

Mean effect of aqueous fruit extract of B. aegyptiaca on $C$. gariepinus fingerlings is presented in Figure 1. Behavioural responses of $C$. gariepinus fingerlings depend on the concentration of the extract and time of exposure. Induction time decreased with increase in concentration of the extract while recovery time increased with increase in concentration of the fruit extract. Statistics reveal significant correlation $(\mathrm{P}<0.01)$ between concentration of the fruit extract and induction time as well as between fruit extract concentrations and survival of fingerlings. After exposure to the lowest concentration $(2.00 \mathrm{~g} / \mathrm{L})$ of the fruit extract the fingerlings loss their normal behaviour (NM) after
$10.35 \pm 0.15 \mathrm{~min}$. The mean time taken to loss normal behaviour decreased to $9.35 \pm 0.45 \mathrm{~min}$ in $2.50 \mathrm{~g} / \mathrm{L}$ concentration of the fruit extract. The mean time of loss of normal behaviour continued to decrease progressively from $6.45 \pm 0.05$ to $5.30 \pm 0.20$ and $4.35 \pm 0.15 \mathrm{~min}$ in $3.00,3.50$ and $4.00 \mathrm{~g} / \mathrm{L}$ of the fruit extract respectively. In the light sedation stage (LS) C. gariepinus fingerlings show slight loss of reactivity to external stimuli and slight decrease in opercula ventilation rate in the lowest concentration $(2.00 \mathrm{~g} / \mathrm{L})$ of the fruit extract at mean time of $15.15 \pm 1.05 \mathrm{~min}$. Duration of this behaviour progressively decreased to $14.30 \pm 0.50$, $12.00 \pm 0.40$ and $9.30 \pm 1.15 \mathrm{~min}$ in concentrations $2.50,3.00$, and $3.50 \mathrm{~g} / \mathrm{L}$ respectively. The shortest time $(6.35 \pm 0.45 \mathrm{~min})$ in the light sedation stage was recorded in the highest concentration $(4.00 \mathrm{~g} / \mathrm{L})$ of the fruit extract. 


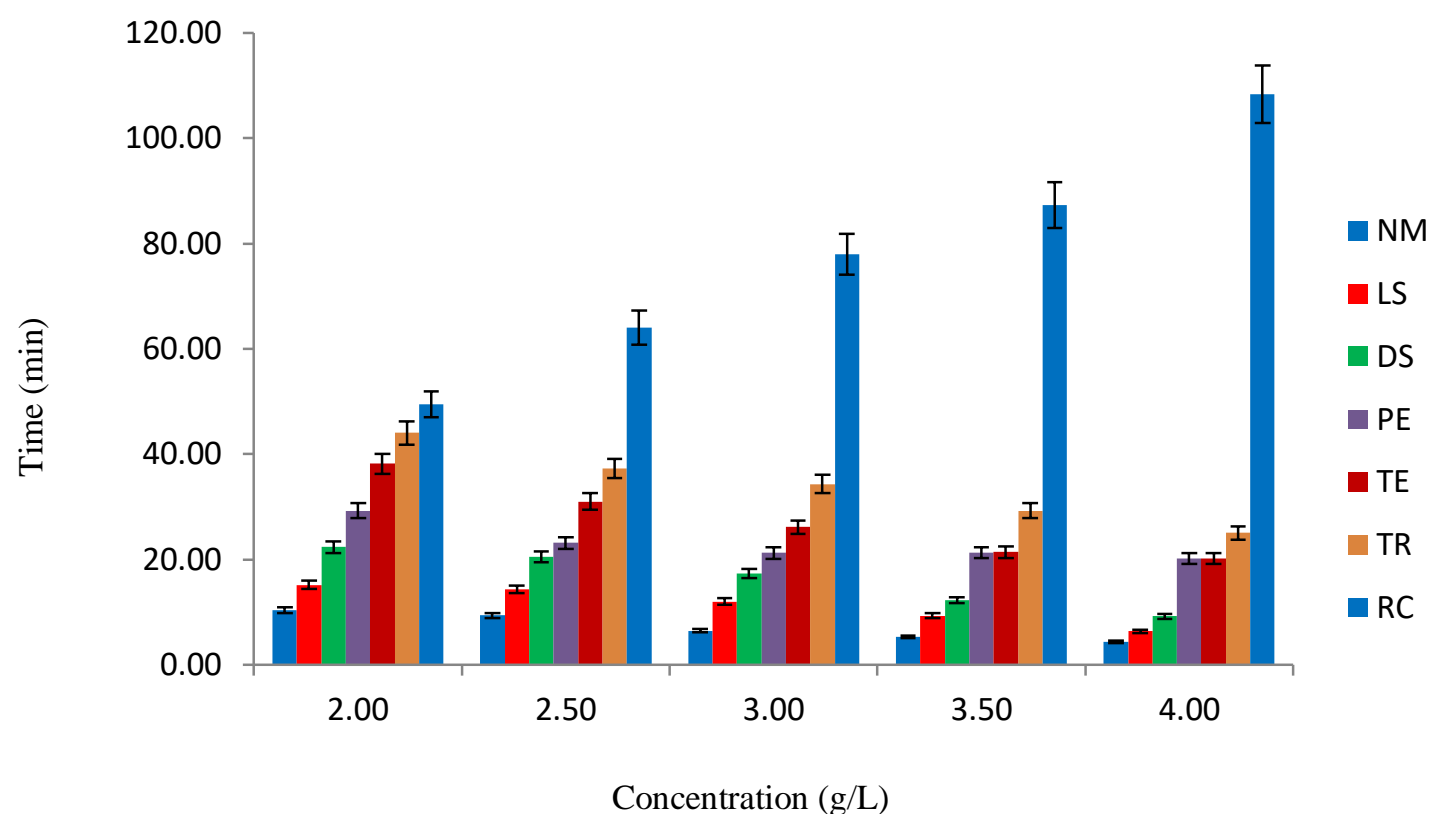

Figure 1: Mean Induction Times of C. gariepinus Fingerlings during Anaesthesia with Aqueous Crude Fruit Extract of B. aegyptiaca $\mathrm{NM}=$ Normal behaviour: Normal swimming and regular opercula ventilation rate, reactive to external stimuli LS=Light Sedation: Normal swimming and regular opercula ventilation rate, reactive to external stimuli

DS=Deep Sedation: Deep fall in opercula ventilation rate, slow swimming and partial loss of reaction to external stimuli.

$\mathrm{PE}=$ Partial loss of equilibrium: Partial loss of muscular tone, erratic swimming, increased opercula ventilation rate and reaction only to strong tactile or vibration stimuli.

TE=Total loss of equilibrium: Total loss of muscular tone and equilibrium, slow and regular opercula movements

TR=Total loss of reflex: Opercula movement is slow and irregular, total loss of reflex and reaction to external stimuli

$\mathrm{RC}=$ Recovery: Restart of opercula movement, erratic movement of the body

The mean time taken for $C$. gariepinus fingerlings to reach deep sedation stage (DS) also decreased with increase in concentration of the fruit extract. The longest mean deep sedation time $(22.35 \pm 0.10 \mathrm{~min})$ was recorded in the lowest fruit extract concentration $(2.00 \mathrm{~g} / \mathrm{L})$ while the shortest time $(9.20 \pm 0.20 \mathrm{~min})$ was recorded in the highest fruit extract concentration $(4.00 \mathrm{~g} / \mathrm{L})$. The longest mean time $(29.25 \pm 1.45$ min) of Partial loss of equilibrium (PE) in C. gariepinus fingerlings was recorded in the lowest concentration $(2.00 \mathrm{~g} / \mathrm{L})$ of the fruit extract while the shortest mean sedation time $(20.15 \pm 0.25)$ was recorded in concentration $4.00 \mathrm{~g} / \mathrm{L}$ of the fruit extract. Fingerlings in the lowest Concentration $(2.00 \mathrm{~g} / \mathrm{L})$ of the extract attained the state of total loss of equilibrium (TE) at mean time of $38.15 \pm 2.35$ min and progressively declined to $20.15 \pm 2.35 \mathrm{~min}$ in the highest concentration $(4.00 \mathrm{~g} / \mathrm{L})$ of the extract. In the total loss of reflex (anaesthetic) stage C. gariepinus fingerlings attained anaesthesia at a mean time of $44.00 \pm 1.35 \mathrm{~min}$ followed by fingerling in the $2.50 \mathrm{~g} / \mathrm{L}$ fruit extract concentration which were anaesthetized at $64.00 \pm 2.00 \mathrm{~min}$. the mean anaesthetization time progressively decreased with increase in fruit extract concentration and the shortest mean anaesthetic time of $25.05 \pm 3.35$ min was recorded in the highest extract concentration $(4.00 \mathrm{~g} / \mathrm{L})$. Statistical analyses revealed significant correlation between fruit extract concentration and recovery time. Mean recovery time of exposed fingerlings increased with increase in fruit extract concentration. The shortest mean recovery time $(49.45 \pm 1.35 \mathrm{~min})$ was recorded in the lowest plant extract concentration $(2.00 \mathrm{~g} / \mathrm{L})$ while the longest mean recovery time of $108.35 \pm 2.45$ min was recorded in the highest plant extract concentration $(4.00 \mathrm{~g} / \mathrm{L})$.

Survival of C. gariepinus fingerlings (Figure 2) in the two lower extract concentrations $(2.00$ and $2.50 \mathrm{~g} / \mathrm{L})$ was $100 \%$ while concentrations 3.00 and $3.50 \mathrm{~g} / \mathrm{L}$ recorded 90 and $80 \%$ survivals respectively. The lowest percentage survival (60\%) was recorded in the highest extract concentration $(4.00 \mathrm{~g} / \mathrm{L})$. The 10,20 and $40 \%$ recorded mortalities in fruit extract concentrations $3.00,3.50$ and $4.00 \mathrm{~g} / \mathrm{L}$ respectively were within 6 to 24 hours after the experiment. 


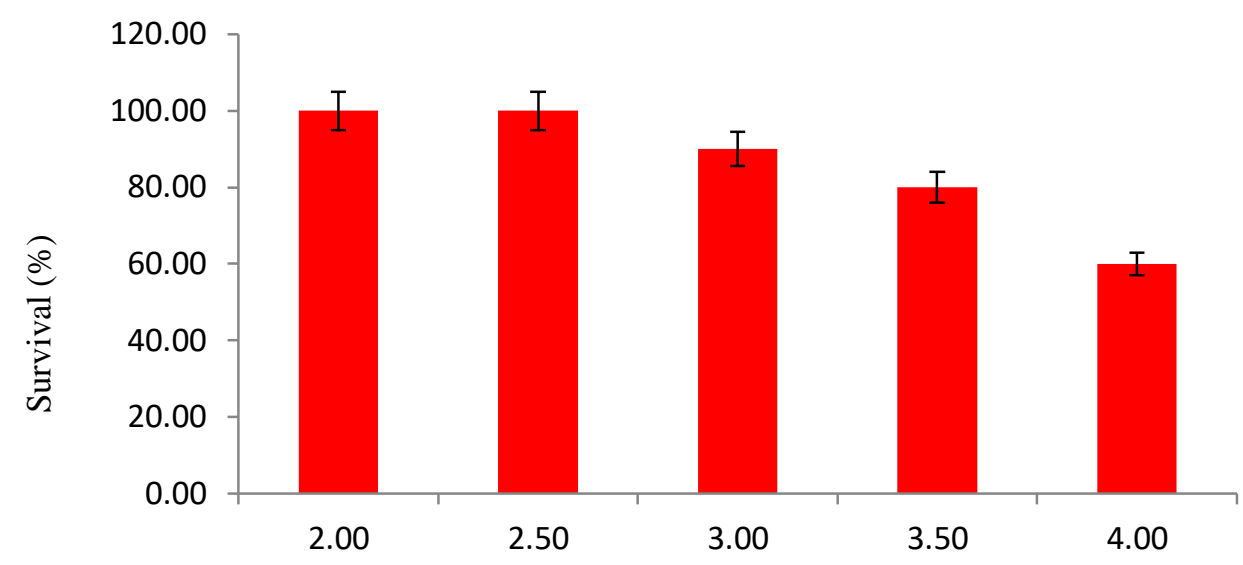

Concentration $(\mathrm{g} / \mathrm{L})$

Figure 2: Mean Percentage Survival of $C$. gariepinus Fingerlings during Anaesthesia with Aqueous Crude Fruit Extract of $B$. aegyptiaca

Opercula Ventilation Rate (OVR) per Minute of $C$. gariepinus Fingerlings during Anaesthesia with Aqueous Crude Fruit Extract of $B$. aegyptiaca

Mean opercula ventilation rate (OVR) per minute of $C$. gariepinus fingerlings during anaesthesia with graded concentrations of aqueous crude fruit extract of $B$. aegyptiaca is presented in Table 4. Statistical analyses showed significant difference $(\mathrm{P}<0.05)$ between OVR of the fingerlings exposed to the treatments compared to those in the control. There was decrease in $\mathrm{OVR} / \mathrm{min}$ as the concentration of the fruit extract increases. The mean $\mathrm{OVR} / \mathrm{min}$ of $C$. gariepinus fingerlings exposed to lowest concentration $(2.00 \mathrm{~g} / \mathrm{L})$ of the fruit extract was $73.15 \pm 0.35$ but progressively decreased to $40.15 \pm 1.00$ in the highest treatment concentration $(4.00 \mathrm{~g} / \mathrm{L})$ while the mean $0 \mathrm{VR} / \mathrm{min}$ of fingerlings in the control was $95.30 \pm 1.00$. Statistically, there is correlation between $\mathrm{OVR} / \mathrm{min}$ of $C$. gariepinus fingerlings and the concentrations of aqueous fruit extract of B. aegyptiaca.

Table 4: Mean Opercula Ventilation Rate (OVR) per min of C. gariepinus Fingerlings during Anaesthesia with Graded Concentrations of Aqueous Crude Fruit Extract of B. aegyptiaca

\begin{tabular}{|l|l|l|l|l|l|l|l|l|l|l|l|}
\hline \multirow{2}{*}{$\begin{array}{l}\text { CONC. } \\
(\mathbf{m g} / \mathrm{L})\end{array}$} & \multicolumn{8}{|c|}{ OVR/MIN OF FINGERLINGS } & $\begin{array}{l}\text { MEAN } \\
\text { OVR/MIN }\end{array}$ \\
\cline { 2 - 11 } & Fish 1 & Fish 2 & Fish 3 & Fish 4 & Fish 5 & Fish 6 & Fish 7 & Fish 8 & Fish 9 & Fish 10 \\
\hline 2.00 & 63.50 & $81.00 \pm$ & 65.50 & $65.50 \pm$ & 66.50 & 78.00 & 80.00 & 83.00 & 82.00 & $66.50 \pm$ & $73.15 \pm 0.35$ \\
& \pm 0.50 & 3.00 & \pm 0.50 & 1.50 & \pm 0.50 & \pm 1.00 & \pm 1.00 & \pm 1.00 & \pm 0.00 & 1.50 & \\
\hline 2.50 & 61.00 & $60.50 \pm$ & 67.50 & $67.00 \pm$ & 74.00 & 63.00 & 62.50 & 59.00 & 61.50 & $60.00 \pm$ & $63.60 \pm 1.00$ \\
& \pm 1.00 & 1.50 & \pm 7.50 & 4.00 & \pm 4.00 & \pm 0.50 & \pm 0.50 & \pm 1.00 & \pm 0.50 & 2.00 & \\
\hline 3.00 & 56.00 & $57.50 \pm$ & 55.00 & $55.50 \pm$ & 59.50 & 61.50 & 56.50 & 57.50 & 54.00 & $55.00 \pm$ & $56.80 \pm 1.60$ \\
& \pm 4.00 & 3.50 & \pm 1.00 & 4.50 & \pm 5.50 & \pm 1.50 & \pm 1.50 & \pm 3.50 & \pm 3.00 & 2.00 & \\
\hline 3.50 & 50.50 & $53.00 \pm$ & 48.50 & $52.00 \pm$ & 47.00 & 47.00 & 48.00 & 50.50 & 50.50 & $50.00 \pm$ & $49.95 \pm 0.35$ \\
& \pm 1.50 & 1.50 & \pm 0.50 & 1.00 & \pm 0.00 & \pm 1.00 & \pm 0.00 & \pm 1.50 & \pm 0.50 & 0.00 & \\
\hline 4.00 & 43.00 & $44.50 \pm$ & 44.00 & $39.00 \pm$ & 41.50 & 41.50 & 36.50 & 37.00 & 37.00 & $37.50 \pm$ & $40.15 \pm 0.15$ \\
& \pm 1.00 & 3.50 & \pm 2.00 & 1.00 & \pm 0.50 & \pm 3.50 & \pm 2.50 & \pm 0.00 & \pm 1.00 & 3.50 & \\
\hline 0.00 & 99.00 & 100.00 & 96.00 & 108.00 & 91.50 & 99.00 & 93.50 & 94.50 & 78.00 & $98.50 \pm$ & $95.30 \pm 1.00$ \\
& \pm 4.00 & \pm 8.0 & \pm 2.00 & \pm 9.0 & \pm 0.50 & \pm 3.00 & \pm 1.50 & \pm 2.50 & \pm 0.00 & 3.50 & \\
\hline
\end{tabular}

\section{DISCUSSION}

Phytochemicals are screened to determine the anaesthetic potential of the plant material. Phytochemicals with anaesthetic properties include alkanoids, flavonoids, terpenoids, cardiac glycosides and anthraquinones (Tsuchiya, 2017) 34. Phytochemicals of crude fruit of $B$. aegyptiaca obtained in Gashua Yobe State, Nigeria include alkanoids, flavonoids, terpenoids, saponins, and cardiac glycosides. Others are tannins, phenols and resins. These show that fruit extract of $B$. aegyptiaca in the present study has anaesthetic potential. The phytochemical constituents of fruit of $B$. aegyptiaca obtained from Gashua is similar to the findings of Salihu et al. (2013) ${ }^{14}$ who screened and reported the presence of alkanoids, saponin, steroid, flavonoids, and cardiac glycosides in fruit mesocarp of B. aegyptiaca collected from Ilorin, Kwara State, Nigeria. The current result also corroborates the work of Vijay et al. (2013) ${ }^{16}$ who reported the presence of alkanoids, flavonoids, glycosides, saponins, and terpenoids in B. aegyptiaca fruit collected from Rajasthan Jaipur, India but not in line with the findings of Kumar et al. (2016) ${ }^{17}$ who reported the absence of alkanoids, tannins, flavonoids and phenols in fruit of B. aegyptiaca collected from Udupi, India.

Proximate compositions of plant parts used in fish study are analyzed to investigate the nutrient levels and determine whether the plant part can be incorporated in diets of fish. 
Proximate analyses of crude fruit extract of B. aegyptiaca in the present study recorded moderate percentage crude protein $(16.40 \%)$ but higher than $10.8 \%$ crude protein of flower of the same plant (Umar et al., 2014) ${ }^{18}$ and $1.28 \%$ crude protein of fruit of Psidium guajava (Ekpete et al., 2013) ${ }^{19}$ as well as $1.25 \%$ crude protein of fruit of Musa paradisiaca (Ekpete et al., 2013) 19 and $11.67 \%$ for Brassica oleracea (Emebu \& Anyika, 2011) 21. The crude protein content of $B$ aegyptiaca in the present study is however lower than $21.16 \%$ for Manihot esculentus leaves and $18.80 \%$ for Ceiba pentandra (Raimi et al., 2014) 22. It is also higher than 24.18\% crude protein for Urera trinervis leaf (Marcel \& Bievenu, 2012) 20 Protein is vital for various body functions such as body development, maintenance of fluid balance, formation of hormones, enzymes and sustaining strong immune function (Emebu and Anyika, 2011) 21. The moderate protein value recorded in this study suggests that fruit of $B$. aegyptiaca could be incorporated in animals other than fish diet as a protein supplement owing to the plant's potential to anaesthetize fish Results of the present study revealed low moisture content (3.56\%) compared to $87.30 \%$ for Carica papaya and $89.60 \%$ for malus domestica fruits reported by Ekpete et al. (2013) ${ }^{19}$. Moisture content of the present study is also much lower than that of Ficus capensis leaves (104.53\%) reported by Achi et al, $(2017)^{23}$. Moisture in food determines the shelf life, rate of digestion, and absorption/assimilation of food within the body system (Olumiyiwa, Babafemi \& Johnson, 2004) ${ }^{35}$. The low moisture contents of the parts of B. aegyptiaca are, therefore, indicative of long shelf life, implying that the parts could be dried under ordinary conditions and kept for longer period of time (Okia, Agea, Kwetegyeka, Okiror, Kimondo \&Teklehaimanot, 2013) 36 . Crude fibre (11.60\%) of $B$. aegyptiaca in the present study is comparatively similar to $11.80 \%$ crude fibre of fruit of the same plant reported by Wakawa, Audu \& Sulaiman (2018) ${ }^{37}$ but higher than $0.75 \%$ for Musa paradisiaca, and $0.11 \%$ for citrus lanatus (Ekpete et al., 2013) ${ }^{19}$. The high crude fibre content of fruit of $B$. aegyptiaca indicates that it may aid digestion and softens stool hence ease bowel movement (Ayoola and Adeyeye, 2009) 38. The high ash content $(8.00 \%)$ of $B$. aegyptiaca in this study is comparably similar with that of fresh leaves $(8.89 \%)$ reported by Okia $e$ al. $(2013)^{36}$ and fruit $(6.00 \%)$ reported by Wakawa et al. $(2018)^{37}$ of same plant. Its value, however, is higher than those reported for fruits of Citrus lanatus $(2.50 \%)$ and Irvingia gabonensis $(2.50 \%)$ reported by Ekpete et al. (2013) ${ }^{19}$. The high ash content of $B$. aegyptiaca shows that it may have appreciable amount of mineral elements. The crude lipid content $(10.90 \%)$ recorded in this study is similar to $10.90 \%$ for fruit reported by Wakawa et al. (2018) ${ }^{37}$ but higher than $2.02 \%$ for leaves reported by Okia et al. (2013) ${ }^{36}$ and $4.50 \%$ for flower (Umar et al., 2014) ${ }^{18}$ of same plant.

Efficacy of an anaesthetic depends on certain water quality parameters. Increase in temperature, according to Stehly and Gingerich (1999)39, may increase the efficacy of certain anaesthetic. In this study temperature is not correlated with concentration of the plant extract hence couldn't have affected the efficacy of B. aegyptiaca on anaesthesia of $C$. gariepinus fingerlings. DO in the present study is inversely correlated with the plant extract concentration and also showed significant variation with the control. This result is in agreement with the earlier findings of Audu, Adamu \& Ufodike $(2013)^{40}$ who reported decrease in DO as concentration of Cannabis sativa increases but contradicts the findings of Anju, Solomon \& Cheikyula (2015) ${ }^{41}$ that DO concentration remained constant in all concentrations of Tephropsia vogelii aqueous crude leaf extract during tranquilization of Heterobranchus longifilis. The low DO in the higher concentrations of the extract in this study could have been responsible for the recorded mortalities due to hypoxia
(Environmental Protection Agency (EPA), 200642; Mallya, 2007) ${ }^{43}$.

The present study shows that aqueous fruit extract of $B$. aegyptiaca on C. gariepinus fingerlings followed the patterns of fish anaesthetic suggested by Summerfelt \& Smith (1990) ${ }^{32}$ and Javahery \& Moraldu (2012) ${ }^{2}$. Behavioural responses display by the fingerlings in the treatment tanks in the present study include loss of equilibrium, erratic swimming, jerky movement, air gulping, jumping above the water surface and vertical standing close to the surface of the water. Similar behavioural responses have been reported by Adebola \& Ayo (2014) ${ }^{44}$ and Audu et al. (2013) ${ }^{40}$. These behavioural signs exhibited by experimental fish may be due to disruption of activities of the nervous system and biochemical derangements (Fafioye, Fagade \& Adebisi, 2005) ${ }^{45}$. The increase in mortality rate with increase in concentration of the extract in this study is also similar to the report of Audu, et al. (2017) ${ }^{30}$. The results of the current study however revealed longer induction and recovery times of $C$. gariepinus fingerlings. The mean induction time of $25.05 \pm 3.35 \mathrm{~min}$ and recovery time of $108.35 \pm 2.45$ min recorded in the highest concentration in this study is much longer than the mean induction $(5.18 \pm 0.07 \mathrm{~min})$ and recovery $(30.19 \pm 1.23 \mathrm{~min})$ times of Oreochromis niloticus exposed to aqueous leaf extract of the same plant reported by Wakawa, Audu \& Sulaiman (2019) 46 as well as induction $(7.00 \pm 0.20 \mathrm{~min})$ and recovery times $(68.00 \pm 1.05 \mathrm{~min})$ of Heterobranchus bidorsalis juveniles reported by Adebayo and Olufayo (2017) ${ }^{47}$ during anaesthesia with Datura stramonium leaf extract. The longer recovery time recorded in this study may be due to increased duration of exposure to the plant material which prolonged the anaesthetic effect (Sladky, Swanson, Stockpot, Loomis \& Lewbart, 2001) ${ }^{48}$. The variations in the induction and recovery times of the fingerlings in this study compared with the results of other workers could be due to variation in fish species, anaesthetic compound or induction time.

\section{CONCLUSION}

Conclusively, aqueous fruit extract of B. aegyptiaca is not an effective anaesthetic for $C$. gariepinus fingerlings owing to long induction and recovery times and the high mortality rate of the fingerlings therefore should not be used as anaesthetic for C. gariepinus fingerlings.

Acknowledgement: The authors are grateful to Tertiary Education Trust Fund (TETfund) Nigeria for financial support to this work.

Conflict of Interest: The authors have declared that there is no conflict of interest.

\section{REFERENCES}

1. Neiffer DL, Stamper MA, Fish Sedation, Anaesthesia, Analgesia and Euthanasia: Considerations, Methods, and Types of Drugs. Institute for Laboratory Animal Research (ILAR), 2009; 50 (4): 343-360.

2. Javahery S, Moradlu AH, AQUI-S, New anaesthetic for use in fish propagation. Global Veterinaria, 2012; 9(2):205-210.

3. Matin SMA, Hossain MA, Hashim MA, Clove oil anesthesia in singhi (Heteropneuses fossilis) and Lata (Channa punctatus) fish. The Bangladesh Veterinarian, 2000; 26: 68-73.

4. Javahery S, Nechoubin H, Moradl AH, Effect of anaesthesia with clove oil in fish: A Review. Fish Physiology and Biochemistry, 2012; 38(6): 1545-1552.

5. Stuart NC, Anaesthesia in fish. Journal of Small Animal Practices. 1985; 22: 377-384.

6. Ramanayaka JC, Atapattu NSBM, Fish Anaesthetic Properties of Some Local Plant Materials. Tropical Agricultural Research \& Extension, 2006; 9: 143-148. 
7. Hajek G, Kłyszejko B, Dziaman R, The Anaesthetic effect of Clove Oil on Nile Tilapia, Oreochromis niloticus L. Acta Ichthyologica et Piscatoria, 2006; 36(2): 93-97.

8. Marking LL, Mayer F, Are better anaesthetics needed in fisheries? Fisheries, 1985; 10(6): 2-5

9. Kamble AD, Saini VP Ojha ML, The efficacy of clove oil as anesthetic in Nile tilapia (Oreochromis niloticus) and its potential metabolism reducing capacity. International Journal of Fauna and Biological Studies, 2014; 1(6):1-6

10. Chothani L. Vagshsiya HU. A review on Balanites aegyptiaca Del. (desert date):,phytochemical constituents, traditional uses, and pharmacological activity. Pharmacological Review, 2011; 5(9):55-62.

11. Onyema AM, Chinedu OJ, Ahmad MS, Evaluation of Balanites aegyptiaca Linna. Dlile, stem bark and synthetic surfactant for surface activity. American Journal of Chemistry and Application, 2017; 4(2):11-15.

12. Tesfaye, A. (2015). Balanites (Balanite aegyptiaca) Del., multipurpose tree: a prospective review. International Journal of Modern Chemistry and Applied Science, 2(3), 189-194.

13. Nkunya, M. H., Weenen, H., \& Bray, D. H. (1990). Chemical evaluation of Tanzanian medicinal plants for the active constituents as a basis for the medicinal usefulness of the plants. In K. E. Mshigeni, M. H. Nkuanya, V. Fupi, R. L. Mahunnah, \& E. N. Mshiu (Eds.). Proceedings of International Conference on Traditional Medicinal Plants. Arusha; pp.101-11.

14. Salihu M, Nwozo SO, Oloyede OB, Aqueous extract of Balanites aegyptiaca Del fruit mesocarp protects against $\mathrm{CCL}_{4}$ - induced liver damage in rats. British Journal of Pharmaceutical Research. 2013; 3(4): 917-928.

15. Absalom KV, Nwadiaro PO, Wophill, N, Toxicity of aqueous extract of desert date (B. aegyptiaca linnaeus) on the juveniles of catfish (Clarias gariepinus Teugels, 1986).Journal of Agriculture and Veterinary Science, 2013; 3(3):13-18.

16. Vijay P, Nivedita A, Bellundagi A, Ethanobaotany and qualitative phytochemical analysis of some Indian medicinal plants. International Journal of Chemical \& Pharmaceutical Sciences, 2013; 4(2): 7-11.

17. Kumar KNS, Sangeetha B, Suchitra P, Ravishinkar B, Yashovarma B, Pharmacognosy and quality characterization of Balanites aegyptiaca (L.) Delile fruits. Indian Journal of Natural Products and Resources, 2016; 7(1): 40-50.

18. Umar KJ, Abubakar L, Alhassan B, Yahaya, SD, Hassan, LG, Sani NA, Nutritional profile of Balanites aegyptiaca flower. Vasile Goldis: University Press, 2014. P.169-173.

19. Ekpete OA, Edori OS, Fubara EP, Proximate composition and mineral composition of some Nigerian fruits. British Journal of Applied Science and Technology, 2013; 3(4):1447-1454.

20. Marcel A, Bievenu MJ, Proximate, mineral and phytochemical analysis of the leaves of $H$. myriantha and Urera trinervis. Pakistan Journal of Biological Sciences, 2012; 15(11): 536-541.

21. Emebu PK, Anyika JU, Proximate and mineral composition of Kale (Brassica oleracea) grown in Delta State, Nigeria. Pakistan Journal of Nutrition, 2011; 10:190-194.

22. Raimi MM, Oyekanmi AM, Farombi AG, Proximate and Phytochemical Composition of Leaves of Ceiba pentandra, Manihot esculentus and Abelmoschus esculentus in south western Nigeria. Scientific Research Journal, 2014; 2(4): 30-34.

23. Achi NK, Onyeabo C, Ekelem-Egedigwe CA, Onyeanula JC, Phytochemical, Proximate Analysis, Vitamin and Mineral Composition of Aqueous Extract of Ficus capensis leaves in South Eastern Nigeria. Journal of Applied Pharmaceutical Science, 2017; 7 (3):117-122.

24. Froese R, Daniel, P, (eds). Clarias gariepinus. In FishBase. 2014; March 2014 version. retrieved October 2, 2017 from https://en.wikipedia.org

25. Clay D, Population biology growth and feeding of Africa catfish (Clariasgariepinus) with special reference to juveniles and their importance in fish culture. Archipelago hydrobiology, 1989; 87(4):433 - 438.

26. Hamidu D, The management of water rights and its consequences in Bade Local Government Area of Yobe State. Unpublished master's thesis, Bayero University, Kano, Kano; 2010; 155pp.

27. Trease GE, Evans WC, Pharmacognosy. 13th edition, Bailler Tindal, London 1989. P. 247-762.
28. Sofowora AF, Medicinal Plants and Traditional Medicine in Africa.. John Wiley and sons, New York, 1982, pp.256

29. Association of Official Analytical Chemist [AOAC], Official Methods of Analysis. (18th ed.), Washington. DC. 2006.

30. Audu BS, Omirinde JO, Gosomji IJ, Wazhi PE, Histopathological changes in the gill and liver of Clarias gariepinus exposed to acute concentrations of Vernonia amygdalina. Animal Research International, 2017; 14(1):2576-2587

31. Rezende FP, Pascoal LM, Vianna RA, Lanna EAT, Sedation of Nile tilapia with essential oils: tea tree, clove, eucleptus, and mint oils. Review of Caatinga, 2017; 30(2):479-486.

32. Summerfelt RC, Smith, LS, Methods for fish biology. In C. B. Schreck,, \& P. B. Moyle, (Eds.) Anaesthesia, Surgery and Related Techniques. American Fisheries Society, Bethesda, MD; 1990. P. 213-272

33. American Public Health Association [APHA], Standard Methods for Examination of Water and Waste Water Washington, USA. 1988.

34. Tsuchiya $\mathrm{H}$, Analgesic agents of plant origin: A review of phytochemicals with anaesthetic activity. Molecules, 2017; 22: 1369-1402

35. Olumiyiwa O, Babafemi J, Johnson C H, Patterns of Delay Amongst Pulmonary Tuberculosis Patient in Lagos. BioMedical Public Health, 2004; 4(18):147-245.

36. Okia CA, Agea JG, Kwetegyeka J, Okiror P, Kimondo J, Teklehaimanot Z, Nutritional value of commonly consumed desert date tree products. African Crop Science Journal, 2013; 21(3):657-667.

37. Wakawa A I, Audu BS, Sulaiman Y, Phytochemistry and proximate composition of root, stem bark, leaf and fruit of desert date, Balanites aegyptiaca. The Journal of Phytopharmacology, 2018;7(6): 464-470.

38. Ayoola PB, Adeyeye A, Proximate analysis and nutrient evaluation of some Nigerian pawpaw seeds varieties. Science Focus, 2009; 14(4):554-558.

39. Stehly GR, Gingerich WH, Evaluation of AQUI-STM (efficacy and minimum toxic concentration) as a fish anaesthetic/sedative for public aquaculture in the United States. Aquaculture Research, 1999; 30:365-372.

40. Audu BS, Adamu KM, Ufodike EBC, Behavioural response and opercula ventilation rate of Nile Tilapia (Oreochromis niloticus) fingerlings after anaesthesia with crude leaf extract of marijuana (Cannabis sativa). Applied Science Research Journal, 2013; 1(2): 66-77.

41. Anju TD, Solomon SG, Cheikyula JO, Effects of aqueous crude leaf extract of Tephropsia vogeli as a tranquilizer on the African Catfish, Hetreobranchus longifilis Val. (Pisces 1840). American Journal of Research Communication, 2015; 3(6):45-59.

42. Environmental Protection Agency (EPA), Fish physiology, toxicology and water quality. In: D, Randall, D Y M, Mandy (eds). Proceedings of the Eighth International Symposium, Chongqing, 2006; China between October $12^{\text {th }}$ and $14^{\text {th }}, 2004$.

43. Mallya YJ, The effects of dissolved oxygen on fish growth in aquaculture. Final project, Kingolwira National Fish Farming Centre, Fisheries Division Ministry of Natural Resources and Tourism Tanzania. 2007.

44. Adebola K, Ayo F, Histological changes in liver, gills and kidney of catfish (Heterobranchus bidorsalis) exposed to cypermethrin concentration. International Journal of Histology and Cytology, 2014; $1(4): 31-33$.

45. Fafioye OO, Fagade SO, Adebisi AA, Toxicity of Raphia vinifera, $P$. beauv fruit extracts on biochemical composition of Nile tilapia (Oreochromis niloticus). Biokemistri, 2005; 17:137-142.

46. Wakawa A I, Audu BS, Sulaiman Y, Anaesthetic effects of aqueous crude leaf extracts of Desert date (Balanites aegyptiaca) on Nile tilapia Oreochromis niloticus) fingerlings. International Journal of Fisheries and Aquatic Studies, 2019; 7(1): 147-152.

47. Adebayo SF, Olufayo MO, Anaesthetic effects of Datura stramonium Leaf on Heterobranchus bidorsalis Juveniles. International Journal of Fisheries and Aquatic studies, 2017; 5(2):590-593.

48. Sladky KK, Swanson CR, Stockpot MK, Loomis, MR, Lewbart GA, Comparative efficacy of tricaine methanesulfonate and clove oil for use as anesthetics in Red Pacu (Piaractus brachypomus). American Journal of Veterinary Research, 2001; 62(3):337-342. 